\title{
Japan's opposition falls into line on plutonium policy
}

Tokyo. The last vestige of domestic political opposition to Japan's policy of using recycled plutonium in nuclear power melted away last week, when the Social Democratic Party (SDP) backed down on its longstanding criticisms.

The SDP was the leading opposition party during 36 years of Liberal Democratic Party (LDP) rule that ended last year, and since then has been a member of the ruling coalition government. At a meeting to set budget allocations for the Science and Technology Agency (STA) in 1995, the SDP, which is headed by the prime minister Tomiichi Murayama, abandoned its role as champion of the anti-nuclear movement.

Instead, the party accepted the LDP policy calling for more money to be spent on explaining the need for plutonium to the public. Among the new initiatives passed by the meeting is a plan to release information on Japan's plutonium use on the worldwide Internet computer network.

Japan's plans to import and subsequently to produce large amounts of plutonium has raised objections from around the world, many triggered by the start of imports of reprocessed plutonium from Europe by ship last year. Furthermore, Japan has found itself in the politically awkward position of having to criticize North Korea's use of plutonium at a time when it is planning rapidly to expand its own supplies of the material.

At first, SDP members of the coalition government insisted that the plutonium issue be reviewed and its use capped at current levels "in keeping with the sentiment of the international community". The SDP also proposed that the electric power industry should be prohibited from using plutonium where it was not profitable.

But Japan's programme to develop com- mercial fast-breeder reactors able to use the plutonium as fuel has been repeatedly delayed (see Nature 369, 569; 1993). To cope with the growing supplies of plutonium (expected to reach about 70 tonnes by 2010) that cannot be stockpiled without violating the Nuclear Non-Proliferation Treaty, Japan's nuclear-power industry plans to mix it with ordinary uranium fuel and burn it in conventional reactors.

This is a very uneconomical way to use plutonium. But the SDP, which has seen some of its key policies compromised during the coalition administration, had its opposition to the current plutonium policy quickly squashed by members of the LDP at the meeting.

Instead, $¥ 142.1$ billion (US\$1.42 million) has been allocated to the STA for the "steady development of the recycling of nuclear fuel" in 1995, two per cent more than in 1994. Included in the allocation is $¥ 110$ million for two "public information rooms", and another $¥ 20$ million for release of information on Internet.

This has already begun. The week before the budget meeting, the Atomic Energy Commission published for the first time a detailed breakdown of Japan's inventories of plutonium in its annual white paper (see table below). This showed that, as of December 1993, Japan had about 10 tonnes of plutonium, with about 4.7 tonnes stored in Japan, and the rest in reprocessing facilities in Britain and France.

But although the promoters of plutonium policy seem to have won the day, their critics say that the worldwide release of such information will only lead to greater criticism of Japan's policy, which is out of line with a worldwide trend away from the use of plutonium and fast-breeder reactors.

David Swinbanks

Separated plutonium at nuclear facilities within Japan.

\begin{tabular}{|c|c|c|c|c|c|c|}
\hline & $\begin{array}{l}\text { PNC } \\
\text { Tokai } \\
\text { Plant }\end{array}$ & $\begin{array}{l}\text { PNC } \\
\text { Tokai } \\
\text { Works }\end{array}$ & Fugen & Joyo & Monju & $R \& D$ \\
\hline $\begin{array}{l}\text { Plutonium in nitrate form (plutonium nitrate in } \\
\text { process area, storage area or conversion area) }\end{array}$ & 288 & & & & & \\
\hline $\begin{array}{l}\text { Plutonium in oxide form (plutonium oxide } \\
\text { stored in containers at storage areas }\end{array}$ & 38 & 2,339 & & & & \\
\hline $\begin{array}{l}\text { Plutonium oxide in fabrication process or } \\
\text { under utilization such as analytical testing }\end{array}$ & & 790 & & & & \\
\hline $\begin{array}{l}\text { Plutonium in fresh MOX fuel element (plutonium } \\
\text { contained in MOX fuel assemblies at storage area) }\end{array}$ & & 140 & & & & \\
\hline $\begin{array}{l}\text { Plutonium in unirradiated MOX fuel assemblies helc } \\
\text { in fresh fuel storage areas at reactor facilities } \\
\text { or fresh plutonium used for R\&D purposes }\end{array}$ & & & 15 & 637 & 12 & 425 \\
\hline TOTAL & 326 & 3,269 & 15 & 637 & 12 & 425 \\
\hline
\end{tabular}

\section{Space scientists are charged in Indian spy-ring scandal}

New Delhi. Security at India's space installations has been strengthened following the arrest of six members of an alleged spy-ring, including two senior scientists of the Indian Space Research Organisation (ISRO). The scientists are said to have sold space secrets for sex and money.

Those being held by the Kerala State police include the Indian representative of Glavkosmos, the Russian space agency, and a business associate. Together with the ISRO rocket experts, the two have been charged with passing national secrets to two women of Maldivian nationality. The women are also in judicial custody.

The scandal has shocked ISRO. One of the scientists arrested is deputy director of the liquid propulsion systems centre (LPSC) at Valiamala near Trivandrum, close to India's southern tip. The second is chief of the rocket fabrication division at the same centre.

About 20 other employees holding key positions at the centre are being kept under surveillance or house arrest pending formal charges. Last week, the Central Bureau of Investigation (CBI), India's main security agency, took over the case.

As well as constructing control systems and apogee motors for spacecraft, LPSC makes liquid engines, according to a French design, for ISRO's polar satellite launch vehicle. These engines are identical to an early version of the Viking engines that power the first stage of Europe's Ariane rocket.

The centre is also responsible for the design and construction of the cryogenic stage for India's geostationary launch vehicle. The involvement of the Glavkosmos agent has fuelled speculation that the targets of the alleged spies were the cryogenic engines that Glavkosmos is supposed to deliver to ISRO beginning next year (see Nature 368, 577; 1994).

ISRO says the scandal will not upset its space programmes. Nor will it harm national security, as ISRO does not handle military projects. But officials within the organization acknowledge that the leaked information could help saboteurs.

Alhough the spy network is alleged to have been operating for at least four years, the CBI is taking no chances. It is now investigating whether there may also be spies at ISRO's other installations, such as Vikram Sarabhai Space Centre in Trivandrum, which designed the first stage of India's ballistic missile 'Agni'.

Indian security agencies believe the spy network was run by a third country, using the Maldivians as either couriers or bait. Pakistani authorities have vigorously denied suggestions that they may have been involved. K. S. Jayaraman 